\title{
Characterisation of the Spectral-Temporal Pattern of the Crambe Crop Using Hyperspectral Sensors
}

\author{
Octavio Henrique Viana ${ }^{1}$, Erivelto Mercante ${ }^{1}$, Henrique Felipetto ${ }^{1}$, Douglas Kusminski ${ }^{1}$ \\ \& Helmuth Guilherme Bleil $\mathrm{Jr}^{2}$ \\ ${ }^{1}$ Western Paraná State University (UNIOESTE), Cascavel, PR, Brazil \\ ${ }^{2}$ University Center Fundação Assis Gurgacz-FAG, Cascavel, PR, Brazil \\ Correspondence: Octavio Henrique Viana, Western Paraná State University (UNIOESTE), Cascavel, PR, Brazil. \\ E-mail: octaviohviana@gmail.com
}

Received: June 18, 2017

doi:10.5539/jas.v9n11p220
Accepted: September 30, 2017 Online Published: October 15, 2017

URL: https://doi.org/10.5539/jas.v9n11p220

\begin{abstract}
Crambe is an oleaginous plant mainly cultivated in Brazil due to its oil characteristics that provide stability to oxidation, qualifying it for the use in a variety of products. Understanding the spectral-temporal pattern of the crambe crop is important to identify and quantify already cultivated areas via remote sensing. This study spectrally characterised the plant, seeking to relate the spectral pattern to the phenological stages of the crop throughout its development. The spectral information was obtained by passive terrestrial sensors in two harvests, thus generating a spectral-temporal pattern and the crambe temporal profile through the vegetation indices NDVI and SAVI. During the phenological stages of the seedling and the beginning of the vegetative growth, the red spectral band showed higher values of reflectance; this occurred because the crop had not yet completely covered the soil. Stages at the end of the vegetative growth and the beginning of the flowering, there was a higher reflectance in the near infrared and a lower reflectance in the mid-infrared. For the granulation and maturation stages, the reflectance in the mean and near infrared reduced due to leaf senescence and loss of cellular water content. The NDVI and SAVI temporal profiles demonstrate linear growth up to the vegetative peak, which occurs between the end of the phenological stage of the vegetative growth and the beginning of the flowering and highest amount of green biomass. At the beginning of grain formation and filling, yellowing of leaves and senescence, granulation and maturation stages, the values reduced.
\end{abstract}

Keywords: remote sensing, spectral behaviour, brassicaceae, Crambe abyssinica H., vegetation indices, agricultural monitoring

\section{Introduction}

Crambe is a cruciferous plant originating from Ethiopia, with a seed oil content of up to $38 \%$ (Knights, 2002). Its development is composed of different phenological stages: seedling, vegetative growth, flowering, granulation and maturation. It has a short cycle, between 78 days and 125 days, depending on the region of cultivation and sowing time (Viana, 2013; Oliveira et al., 2013).

It stands out as an alternative in biodiesel production in Brazil due to its rusticity, early maturation, high oil content and adaptability to different climates (Souza et al., 2016). The Fundação MS implemented crambe in 1995 in the country, which is currently a commercial variety cultivated for the production of oil used in industrial lubricants, corrosion inhibitors, plastic films, nylon, adhesives and electrical insulators (Pitol, Broch, \& Roscoe, 2010; Jasper, 2010).

Research conducted in the state of Paraná during the winter harvest showed a grain production between 1.500 and $2.100 \mathrm{~kg} / \mathrm{ha}$ and an oil yield from 500 to $700 \mathrm{~kg} / \mathrm{ha}$ (Silva et al., 2013; J. I. Santos, Silva, Rogerio, R. F. Santos, \& Secco, 2013; Viana et al., 2015).

Remote sensing techniques are important tools for monitoring the development and expansion of areas cultivated with agricultural crops, in addition to subsidising production estimates at the regional and national levels. Such techniques allow crop characterisation from reflectance data generated in the spectral ranges of the visible, near infrared - NIR and mid-infrared - MIR, besides conversion of the acquired data (Lohmann, Deppe, Simoes, \& Mercuri, 2009). 
Coutinho, Esquerdo, Oliveira, and Lanza (2012) state that in order to map and monitor areas of annual agriculture, spatial and temporal information of the national agricultural activity is required, synchronised with the phenological development of the crops. This characterises the spectral-temporal behaviour that supports the accurate assessment of the productive potential of the plants.

However, mapping agricultural crops by remote orbital sensing is still a challenging undertaking. Under full soil coverage conditions, for most current orbital sensors, different crops may appear to be spectrally similar (Yao, Tang, Wang, \& Zhang, 2015). To change this, new technologies have been tested in terms of their potential for spectral differentiation. With the use of hyperspectral sensors, images with hundreds of narrow and continuous spectral bands are acquired. Thus, hyperspectral images have substantially improved the ability to distinguish multiple characteristics of agricultural crops by better differentiation and estimation of biophysical attributes (Mulla, 2013).

Field spectroradiometers perform in situ radiometric collections, thus providing not only detailed data on the spectral characteristics of targets, but also allowing the acquisition of physical values, such as radiance and reflectance, which spectrally characterise different objects without the interference of external factors (Martins \& Galo, 2015).

Vegetation indices (VIs) are spectral measurements from mathematical combinations of spectral ranges from red $(620$ to $700 \mathrm{~nm})$ and near infrared (NIR) (700 to $1.300 \mathrm{~nm}$ ), which provide more than $90 \%$ of the spectral information of vegetation (Viña, Gitelson, Nguy-Robertson, \& Peng, 2011). According to Motomiya et al. (2014), VIs are generally related to biomass, chlorophyll content and the productive potential of plants.

The normalised difference vegetation index (NDVI) and the soil-adjusted vegetation index (SAVI) are among the most used indices to monitor the biomass temporal evolution of agricultural crops (Ponzoni, Shimabukuro, \& Kuplich, 2012). Research has shown that they are important tools in monitoring crop development (Risso et al., 2012) and correlate with grain yields (Bredemeier, Variani, Almeida, \& Rosa, 2013; Monteiro, Angulo Filho, Xavier, \& Monteiro, 2013). A time series of NDVI values of agricultural crops throughout their vegetative cycle can provide useful information on growth and crop state (Li et al., 2014).

In this context, this study aimed to characterise the spectral-temporal pattern of the crambe, obtained by a passive terrestrial sensor, and tried to relate the spectral pattern of the crambe crop with its phenological stages. Such an approach could provide a technical basis for the potential use of satellite images (SR orbital) in order to identify, delimit, map and monitor agricultural areas cultivated with crambe on a large scale.

\section{Material and Methods}

\subsection{Characterisation of the Study Area and Crop Implantation}

The study was conducted during the 2014 and 2015 harvests in the experimental areas of the University Center FAG, Cascavel city of Paraná state, Brazil, latitude $24^{\circ} 56^{\prime} 1.21^{\prime \prime} \mathrm{S}$ and longitude $53^{\circ} 30^{\prime} 41.63^{\prime \prime} \mathrm{W}$, at an altitude of $700 \mathrm{~m}$ (Figure 1). 


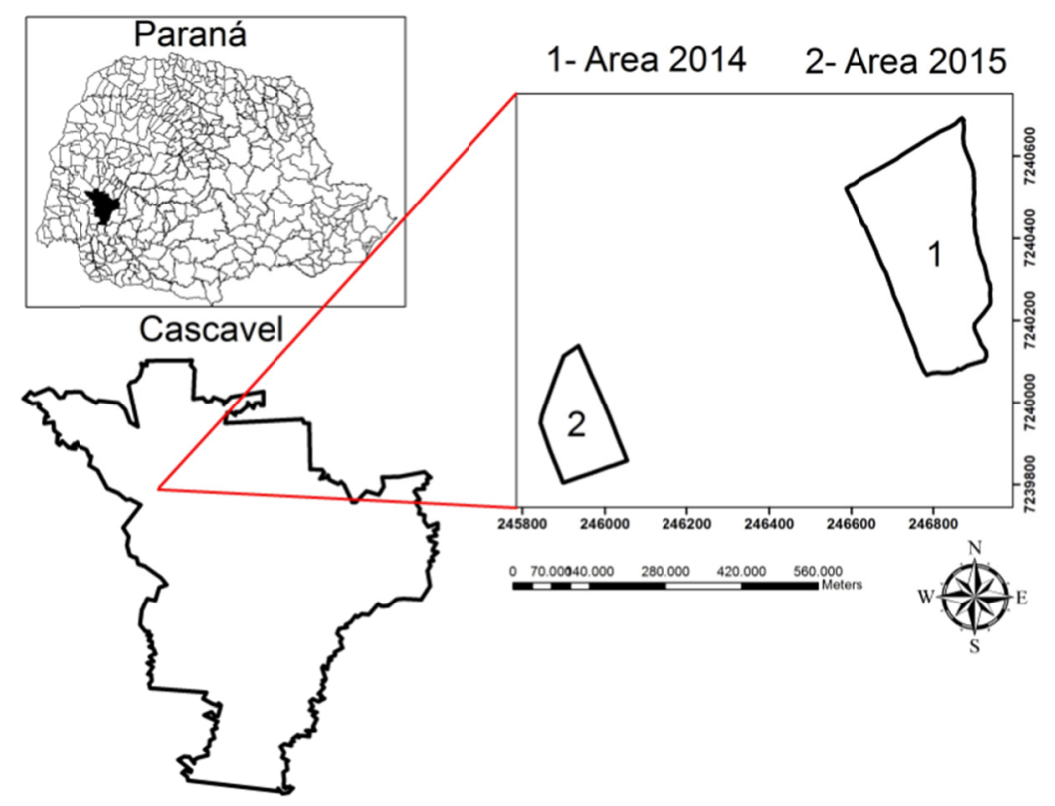

Figure 1. Experimental areas of crambe, Cascavel-PR

The climate, according to Köppen, is characterised as Cfa, with average temperatures in the coldest month below $18{ }^{\circ} \mathrm{C}$ (mesothermic) and in the hottest month above $22^{\circ} \mathrm{C}$. Rainfall is concentrated in the summer months; frost is infrequent and there is no defined dry season (Instituto Agronômico do Paraná [IAPAR], 2011). The soil is classified as distroferric Red Latosol (LVdf1) (Empresa Brasileira de Pesquisa Agropecuária [EMBRAPA], 2011).

In 2014 and 2015, 12 hectares (ha) and 4 ha of the crop were implanted, respectively. At harvest, crambe was sown in the second half of April in a no-till system, in an area previously cultivated with corn and soybean. Seeds of the variety FMS Brilhante were implanted with the aid of a tractor and a seeder/fertiliser; there were nine rows with a spacing between rows of $0.45 \mathrm{~m}$ and a density of $12 \mathrm{~kg} / \mathrm{ha}$ seeds ( 36 plants per meter), with no basic fertilisation.

\subsection{Experimental Design}

The experimental design for collecting the spectral information in the 2014 harvest was determined from the observation unit comprised by the 12 ha crambe field. Twelve sample points characterised as experimental unit were randomly selected and demarcated. Plants near the field boundary were not selected to avoid edge effects (Figure 2). 


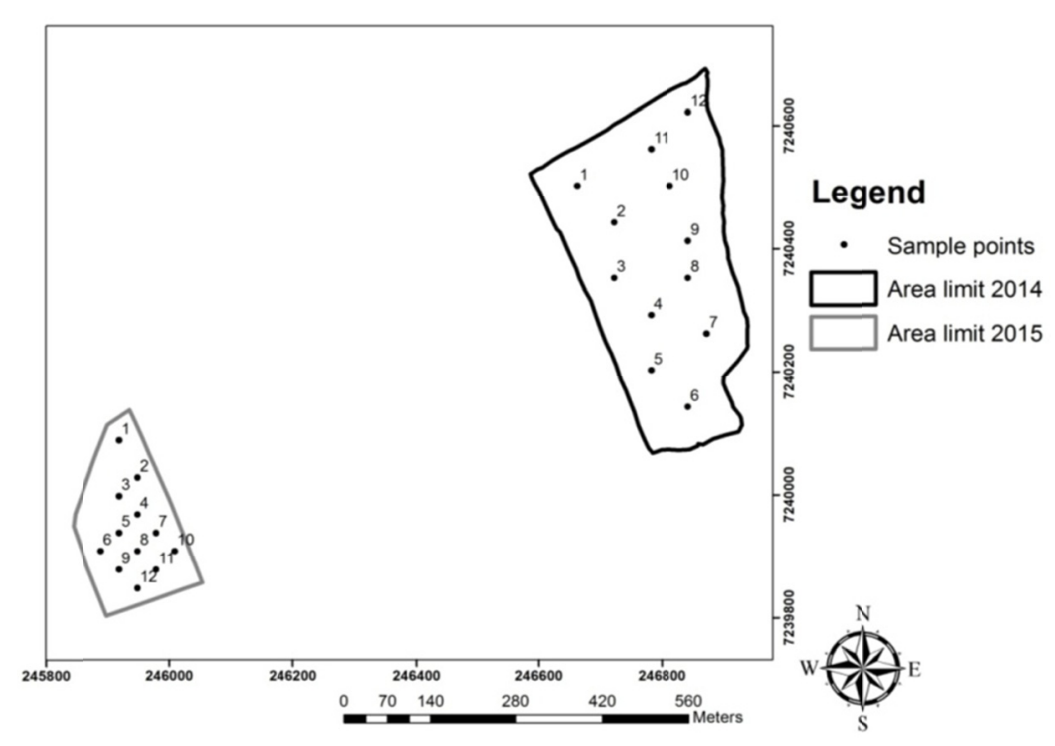

Figure 2. Crambe observation units 2014 and 2015

The same procedure was carried out for the experimental design of the 2015 harvest, considering a 4 ha field sown with crambe as observation unit (Figure 2). At harvesting, in each experimental unit, four collections (repetitions) of the hyperspectral information were performed.

\subsection{Collections of Hyperspectral Information}

At the 2014 harvest, hyperspectral information was collected at 5 different days during crop development, while in 2015 , we collected information on 7 days (Table 1).

Table 1. Calendar of crambe spectral information-2014 and 2015 harvests

\begin{tabular}{lll|lll}
\hline Harvest & Collection $\left(\right.$ DAS $\left.^{*}\right)$ & Phenological stage & Harvest & Collection $\left(\mathrm{DAS}^{*}\right)$ & Phenological stage \\
\hline & 24 & Seedling/Vegetative Growth & & 21 & Seedling/Vegetative Growth \\
& 41 & Vegetative Growth & & 34 & Vegetative Growth \\
2014 & 56 & Flowering & 48 & Vegetative Growth \\
& 88 & Flowering/Granulation & 2015 & 66 & Flowering \\
& 104 & Maturation & & 80 & Flowering/Granulation \\
& & & 96 & Granulation \\
& & & 114 & Maturation \\
\hline
\end{tabular}

Note. ${ }^{*}$ DAS: Days after sowing.

In the two harvesting years, data was collected every 16 days, based on a temporal resolution similar to the Landsat 8 satellite. In 2014, due to climatic conditions which impeded the collection of information, we changed the temporal resolution. However, in the two harvests, it was possible to collect spectral information in all phenological stages of the crop (EM - emergence; PL - seedling, VG - vegetative growth; FL - flowering; GR granulation; MT - maturation).

We obtained the spectral data through the passive mode of the hyperspectral sensor FieldSpec ${ }^{\circledR} 4 \mathrm{Hi}-\mathrm{Res}$, which operates at wavelengths $(\lambda)$ from $350 \mathrm{~nm}$ to $2500 \mathrm{~nm}$. The information was collected at 0.80 meters $(\mathrm{m})$ canopy height, positioning the optical fibre between sowing lines with a range of $0.45 \mathrm{~m}$ and a field of view of $25^{\circ}$ (IFOV Instantaneous Field of View).

All measurements were taken from 10:00 am to $12: 00 \mathrm{pm}$, obtaining the maximum daily solar radiation. In the field, every 20 minutes, the sensor was optimised and we obtained a white reference on the Spectralon ${ }^{\circledR}$ surface, defined as maximum reflectance (1 or 100\% reflectance) (ASD Inc., 2012). 


\subsection{Characterisation of the Spectral-Temporal Signature}

The hyperspectral information of the 12 sample points was grouped by day of harvest in the software Excel, calculating the daily means; graphs of the spectral-temporal signature of each harvest were designed.

\subsection{Calculation of Vegetation Indices}

Daily averages of each sampling point were generated, totalling 12 mean samples per collection day. To calculate the Normalized Difference Vegetation Index (NDVI), spectral range information was selected from 620 to 1300 $\mathrm{nm}$, classified into two spectral bands: V - Red (620 to $700 \mathrm{~nm}$ ) and NIR - Near infrared (700 to $1300 \mathrm{~nm}$ ), and applied in the formula proposed by Rouse, Hass, Schell \& Deering (1974), according to Equation 1.

$$
N D V I=(\rho I V P-\rho V) /(\rho I V P+\rho V)
$$

Where,

$\rho I V P$ : Range of near infrared; $\rho V$ : Range of red.

Another index generated from the daily mean sample was the Soil-Adjusted Vegetation Index (SAVI), based on the formula proposed by Huete (1988), who introduced an adjustment factor (L) between -1 and +1 , Equation 2 .

$$
S A V I=(\rho I V P-\rho V) \cdot(1+L) /(\rho I V P+\rho V+L)
$$

Where,

$\rho I V P$ : Range of near infrared; $\rho V$ : Range of red; $L$ : Adjustment factor for the canopy substrate of the plant, which takes into account differential canopy extinction for red and near infrared (Huete, 1988).

Huete, Justice and Liu (1994) found that by applying $L=0.5$, the soil brightness variations were minimised, eliminating the need for additional calibration for different soil and canopy types.

\subsection{Statistical Analysis}

The VIs were tabulated and graphs were generated with the temporal profiles of the daily means of NDVI and SAVI of the crambe in the 2014 and 2015 harvests. Both profiles were submitted to the normality test using the Shapiro-Wilk method and exploratory data analysis in the software Action Stat.

\section{Results and Discussion}

Crambe showed a growth cycle of around 120 days in the two harvests. In 2014 and 2015, cumulative precipitation was 832 and $827 \mathrm{~mm}$, respectively. According to Pitol et al. (2010), precipitation excess during crop development favours the appearance of fungal diseases that affect grain yield.

\subsection{Characterisation of Spectral-Temporal Patterns}

\subsubsection{Harvest}

Figure 3 represents the spectral signature at different crambe developmental stages. The curve that includes the spectral data mean of the phenological stages of PL and beginning of VG - 21 DAS (Days After Seeding) shows the highest reflectance of the red spectral range $(620$ to $700 \mathrm{~nm})$ when compared to curves 41, 56 and 88 DAS. This fact was related to the large soil area still exposed during data collection; in these phenological stages, the soil was only partially covered by the crambe canopy. The soil of the experimental area was rich in iron oxide, causing the red tonality, which may have contributed to this behaviour (Sousa Jr., Demattê, \& Genú, 2008; Genú \& Demattê, 2012).

The phenological stage curves of VG and FL, 41 and 56 DAS, show a gradual increase in the absorption of blue (400 to $500 \mathrm{~nm}$ ) and red $(620$ to $700 \mathrm{~nm})$ wavelengths. According to Ponzoni et al. (2012), the chlorophyll in the green leaves absorbs these spectral regions, converting heat and stored energy through photosynthesis. These curves, compared to the beginning of the cycle (21 DAS), show an increase in the reflectance of the green range due to leaf pigmentation.

The highest reflectances in the NIR range (near infrared; 700 to $1300 \mathrm{~nm}$ ) are represented in the phenological stage curves of FL and FL/GR, 56 and 88 DAS, with the reflection peak in the stage that includes the beginning of flowering. Jensen (2009) emphasises that the energy incident on the structure of a green and healthy leaf generates scattering in the spongy mesophyll and increase in reflectance. Figure 3 shows examples of this occurrence in crambe leaves at 56 DAS.

The MT stages of the plant, 104 DAS curve, are characterised by the reflectance increase in the MIR range (1300 to $3200 \mathrm{~nm}$ ). Leave senescence and water loss in the cell structure contribute to this behaviour, according to the field situation in 104 DAS, presented in the image of this day (Figure 3). 


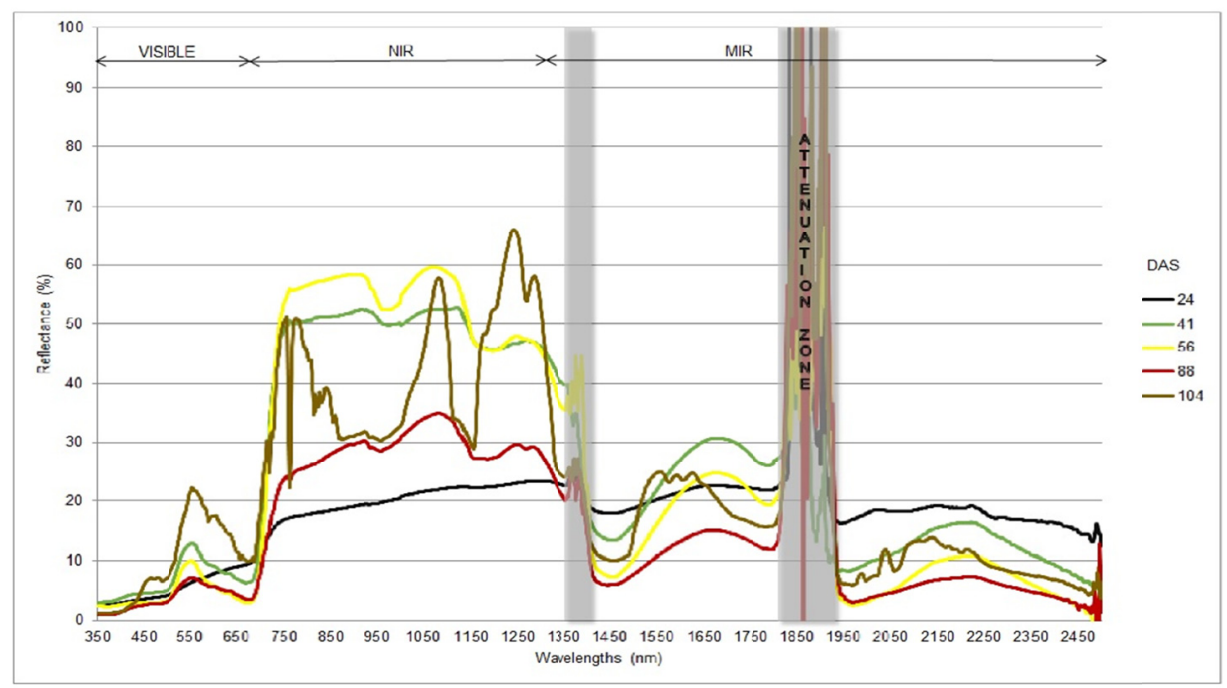

DAS: 24

41

56

88

104
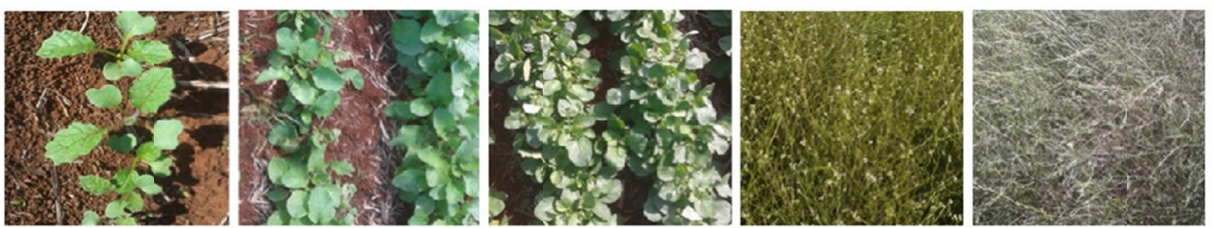

Figure 3. Daily means of spectral signatures based on collection days over the development cycle of crambe, 2014 harvest

The range shaded in Figures 3 and $4(1400 \mathrm{~nm}, 1800$ to $1900 \mathrm{~nm})$ was disregarded due to the interaction between the electromagnetic energy and the gases in the atmosphere, which prevents the sensing in these spectral bands (Moraes, 2009).

\subsubsection{Harvest}

Figure 4 shows the spectral signature of crambe in the 2015 harvest. The curve representing the mean of 24 DAS, the transition between the phenological stages PL and early VG, behaves similarly to the same phenological stage of 2014 (21 DAS), with a higher reflectance in the red range due to iron oxide in the soil in most of the sensed area. 


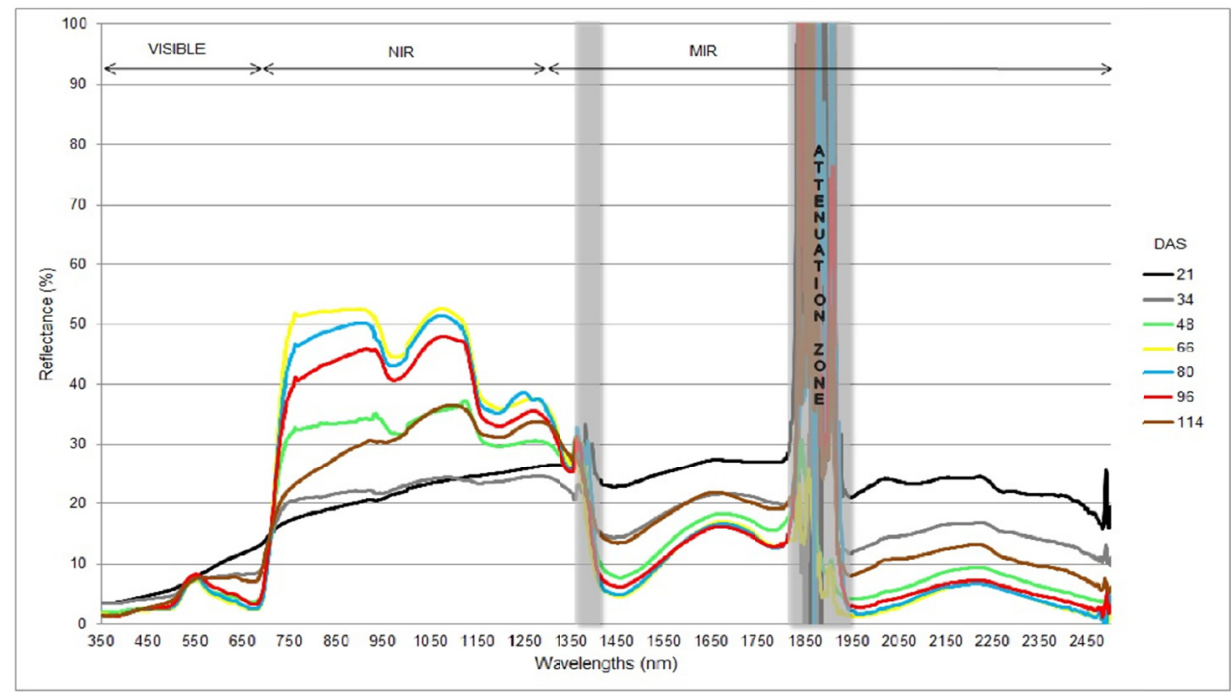

DAS 21

34

48

66

80

96

114
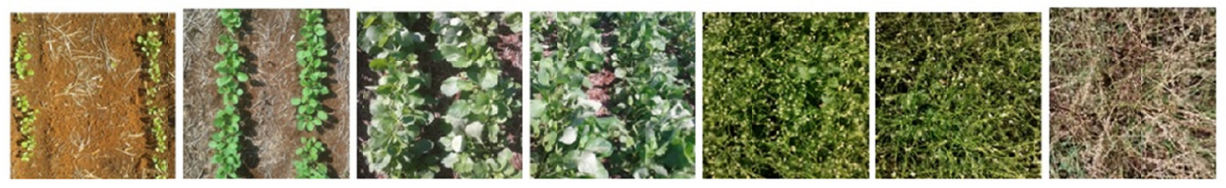

Figure 4. Daily means of spectral signatures based on collection days over the development cycle of crambe, 2015 harvest

The spectral signatures of 34, 48 and 66 DAS, comprised respectively by the phenological stages of VG and FL, show that the plants use energy absorbed in blue and red ranges as a source of energy for growth until reaching the absorption peak in full VG (66 DAS); after this period, the chlorophyll content in the canopy reduces, causing an increase in reflectance. Our results are similar to those obtained in the assessment of photosynthetic capacity of irrigated rice (Inoue, 2008).

In the NIR, these curves show an increase in spectral reflectance with reflection peak (approximately $50 \%$ ), related to high plant biomass in the full vegetative growth (66 DAS). In the MIR range (mid-infrared), the spectral pattern shows an increase in absorption (up to $66 \mathrm{DAS}$ ) due to the increase in water content in the canopy. According to Datt (1998), young leaves with greater photosynthetic activity are responsible for this behaviour.

At the end of the FL stage and in the GR and MT stages, represented by the spectral signatures of 80, 96 and 114 DAS, the red spectral range reflectance gradually increases. In the course of their development, the leaves lose pigmentation and reduce the absorption of the spectral range.

In the NIR, these curves initiate the reflection reduction of the energy incident on the canopy due to modification in the cell structure and approaching senescence. In the MIR spectral range, the inverse occurs; water loss by the canopy leaves reduces energy absorption, especially in the specific ranges of water absorption (1400 and 1900 nm) (Bendini et al., 2015).

The spectral signatures of the 2014 and 2015 show that in the PL and early VG stages, the exposed soil characteristics generate the greatest reflection of the red region of the whole crambe cycle; afterwards, an increase in the absorption by the crambe canopy in the spectral ranges of the red and MIR occurs for energy generation used in the growth and an increase of the water content in the cell structure, respectively, until reaching the phenological stages of full VG and FL. In NIR, an increase in reflectance in these stages occurs.

In the other stages of the development cycle, GR and MT, the canopy loses pigmentation and water content and initiates leave senescence, contributing to the absorption reduction in red wavelengths, reflectance reduction in the NIR and reflectance increase in the MIR. 


\subsection{Vegetation Indices}

\subsubsection{NDVI}

\section{(1) NDVI Statistical Analysis}

The NDVI means of 2014 and 2015, submitted to the Shapiro-Wilk test, presented a p-value of 0.6385 and 0.2500 , respectively. Values greater than the 0.05 significance level represent normality in the data distribution.

Table 2 shows the exploratory data analysis of NDVI of crambe, 2014 harvest. All characterised by low dispersion, the lowest standard deviation (SD) of 0.014 was collected at the beginning of the cycle, PL and early VG stages - 24 DAS and higher during VG in 41 DAS (0.0402). According to Pimentel-Gomes (2002), the NDVI coefficients of variation (2014) are classified as low dispersion and high precision in the experiment.

Table 2. Exploratory analysis of the NDVI vegetation indices of crambe, 2014

\begin{tabular}{llllll}
\hline \multirow{2}{*}{ Statistics } & \multicolumn{5}{c}{ DAS $^{*}$} \\
\cline { 2 - 6 } & 24 & 41 & 56 & 88 & 104 \\
\hline Minimum & 0.3455 & 0.6779 & 0.8184 & 0.7065 & 0.4927 \\
Mean & 0.3651 & 0.7393 & 0.8505 & 0.7247 & 0.5416 \\
Median & 0.3636 & 0.7389 & 0.8549 & 0.7179 & 0.5440 \\
Maximum & 0.394 & 0.8016 & 0.8736 & 0.7514 & 0.5735 \\
SD $^{* *}$ & 0.014 & 0.0402 & 0.0164 & 0.0148 & 0.0247 \\
CV $^{* * *}(\%)$ & 3.82 & 5.44 & 1.92 & 2.04 & 4.56
\end{tabular}

Note. ${ }^{*} \mathrm{DAS}=$ Days after sowing, ${ }^{* *} \mathrm{SD}=$ Standard deviation, ${ }^{* * *} \mathrm{CV}=$ Coefficient of variation.

Table 3 shows the NDVI exploratory data analysis of the crambe, 2015 harvest. Low dispersion and high precision are data characteristics, except the values generated during the VG - 34 DAS. The lowest standard deviation and the lowest coefficient of variation were obtained in FL/early GR in 80 DAS, 0.005 and $0.58 \%$, respectively. The highest SD (0.0556) and a CV of 12.51\%, classified by Pimentel Gomes (2002) as mean dispersion, were found in 34 DAS in the VG stage.

Table 3. Exploratory analysis of the NDVI vegetation indices of crambe, 2015

\begin{tabular}{llllllll}
\hline \multirow{2}{*}{ Statistics } & \multicolumn{7}{c}{ DAS $^{*}$} \\
\cline { 2 - 7 } & 21 & 34 & 48 & 66 & 80 & 96 & 114 \\
\hline Minimum & 0.2655 & 0.3281 & 0.6523 & 0.8616 & 0.8471 & 0.6792 & 0.5078 \\
Mean & 0.2868 & 0.4449 & 0.7638 & 0.8690 & 0.8530 & 0.7934 & 0.5872 \\
Median & 0.2859 & 0.4371 & 0.7748 & 0.8662 & 0.8526 & 0.8039 & 0.5933 \\
Maximum & 0.3126 & 0.5499 & 0.8118 & 0.8798 & 0.8608 & 0.8186 & 0.6806 \\
SD $^{* *}$ & 0.015 & 0.0556 & 0.0435 & 0.0065 & 0.0050 & 0.0378 & 0.0460 \\
CV $^{* * *}(\%)$ & 5.22 & 12.51 & 5.70 & 0.75 & 0.58 & 4.76 & 7.84 \\
\hline
\end{tabular}

Note. ${ }^{*} \mathrm{DAS}=$ Days after sowing, ${ }^{* *} \mathrm{SD}=$ Standard deviation, ${ }^{* * *} \mathrm{CV}=$ Coefficient of variation.

\section{(2) NDVI Temporal Profile}

Figure 5 shows the time profile of NDVI of crambe in the 2014 and 2015 harvests. The indices obtained at the beginning of the cycle, 24 DAS (2014) and 21 DAS (2015), were the lowest in the whole crop cycle, 0.36 and 0.29 , respectively. In both harvests, the plants were in the transition between the PL stages and early VG, unfurling the first true leaves. Plants with small size and on exposed soil contribute to electromagnetic energy absorption in the NIR range, justifying the lowest NDVI values (Poelking, Lauermann, \& Dalmolin, 2007). 


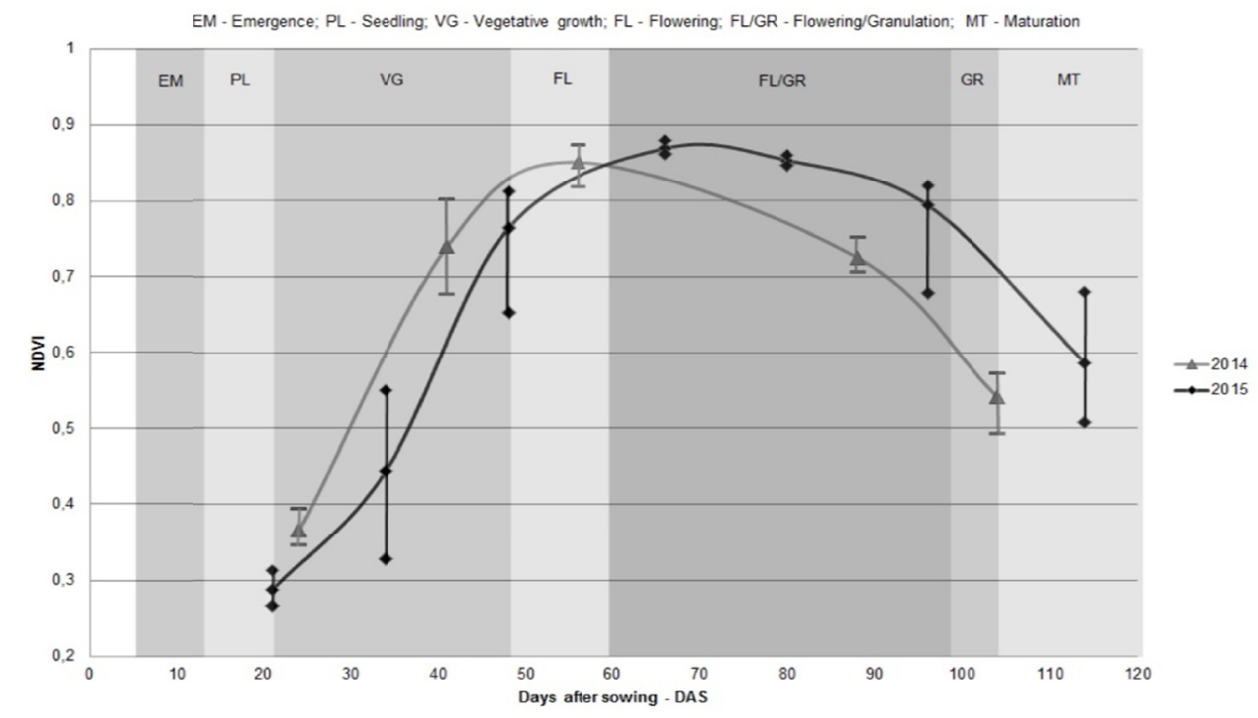

Figure 5. Maximum and minimum values and curve composed by daily means of the Normalised Difference Vegetation Index (NDVI) of crambe, 2014 and 2015 harvest

Risso et al. (2012), in a study in the state of Mato Grosso do Sul aiming to evaluate the performance of the NDVI and EVI indices in the distinction of soybean areas in relation to other soil coverages, found low NDVI values in the crop areas where crop residues and exposed soil predominated. At the beginning of the cycle, the cultivated areas present low responses to NDVI, and the ascension occurs from the vegetative development of the plants (Leivas et al., 2013).

The NDVI presented linear growth for the two harvests until the full VG and FL, reaching the highest crop cycle indices, 0.85 (56 DAS - 2014) and 0.87 (66 DAS - 2015). At these development stages, plants tend to present higher biophysical parameter values, such as biomass and leaf area index as well as NDVI. Studies have shown that vegetation indices such as NDVI are related to these biophysical parameters (Nguy-Robertson et al., 2012; Kross, Mcnairn, Lapen, Sunohara, \& Champagne, 2015).

At the subsequent collection, NDVI values were reduced to 0.72 in 88 DAS (2014) and 0.79 in 96 DAS (2015). In the GR stage, plants use their energy for the filling of grains, with the onset of leaf fall and, consequently, lower leaf area index and NDVI values.

During the MT phase, the NDVI values obtained in 104 DAS (2014) and 114 DAS (2015) decreased to 0.54 and 0.59 , respectively. This NDVI reduction occurs due to the yellowing of leaves caused by senescence (Soudani et al., 2013).

The lines transverse to the curves shown in Figure 5 demonstrate the daily minimum and maximum values of NDVI. In the two harvests, there was greater proximity between these values and the respective mean between the FL and GR stages. According to Zanzarini, Pissara, Brandão, and Teixeira (2013), where there is leaf area index - LAI in the crop, NDVI saturation occurs. Thus, the index stabilises at a plateau even, with an increase in canopy density.

The greatest variations between minimum, mean and maximum values of NDVI were found in the VG and MT stages. The crambe shows unevenness in the maturation of the plants in the field (Oliveira et al., 2014). This was observed during data collection at this phenological stage. Although most plants showed end of cycle characteristics (senescence), there were plants with green pigmentation and plants in the grain filling stage.

\subsubsection{SAVI}

\section{(1) SAVI Statistical Analysis}

The SAVI means of the 2014 and 2015 harvests, submitted to the Shapiro-Wilk test, showed p-values of 0.91 and 0.49 , respectively, representing data normality.

Table 4 shows the exploratory analysis of the SAVI index -2014 harvest. The data obtained in the PL/early VG (24 DAS) and crop maturation stages (104 DAS) showed low dispersion coefficients of variation and high 
precision. Data collected in the VG, FL and GR, represented respectively by 41, 56 and 88 DAS, showed mean dispersion, according to the classification proposed by Pimentel-Gomes (2002).

Table 4. Exploratory analysis of the SAVI vegetation indices of crambe, 2014

\begin{tabular}{llllll}
\hline \multirow{2}{*}{ Statistics } & \multicolumn{5}{c}{ DAS $^{*}$} \\
\cline { 2 - 6 } & 24 & 41 & 56 & 88 & 104 \\
\hline Minimum & 0.1898 & 0.4147 & 0.5327 & 0.2846 & 0.3741 \\
Mean & 0.2056 & 0.5460 & 0.6624 & 0.4016 & 0.4187 \\
Median & 0.2001 & 0.5172 & 0.6456 & 0.3666 & 0.4193 \\
Maximum & 0.2355 & 0.7364 & 0.8518 & 0.5955 & 0.4712 \\
SD $^{* *}$ & 0.0148 & 0.1091 & 0.1072 & 0.0912 & 0.0282 \\
CV $^{* * *}(\%)$ & 7.17 & 19.99 & 16.18 & 22.73 & 6.74 \\
\hline
\end{tabular}

Note. ${ }^{*} \mathrm{DAS}=$ Days after sowing, ${ }^{* *} \mathrm{SD}=$ Standard deviation, ${ }^{* * *} \mathrm{CV}=$ Coefficient of variation.

Table 5 corresponds to the SAVI exploratory analysis - 2015 harvest. Data obtained in 48, 80 and 114 DAS showed low dispersion of data. The other collection days classified by mean data dispersion (CV: 10 to $20 \%$ ).

Table 5. Exploratory analysis of the SAVI vegetation indices of crambe, 2015

\begin{tabular}{llllllll}
\hline \multirow{2}{*}{ Statistics } & \multicolumn{7}{c}{ DAS $^{*}$} \\
\cline { 2 - 8 } & 21 & 34 & 48 & 66 & 80 & 96 & 114 \\
\hline Minimum & 0.1383 & 0.1887 & 0.4323 & 0.4573 & 0.5680 & 0.3839 & 0.3392 \\
Mean & 0.1715 & 0.2602 & 0.4775 & 0.6305 & 0.6148 & 0.5562 & 0.3795 \\
Median & 0.1688 & 0.2592 & 0.4688 & 0.6398 & 0.6086 & 0.5706 & 0.3793 \\
Maximum & 0.2158 & 0.3095 & 0.5553 & 0.8014 & 0.6715 & 0.6192 & 0.4487 \\
SD $^{* *}$ & 0.0225 & 0.0350 & 0.0388 & 0.0789 & 0.0294 & 0.0608 & 0.0303 \\
CV $^{* * *}(\%)$ & 13.11 & 13.45 & 8.13 & 12.52 & 4.77 & 10.93 & 7.97 \\
\hline
\end{tabular}

Note. ${ }^{*}$ DAS $=$ Days after sowing, ${ }^{* *} \mathrm{SD}=$ Standard deviation, ${ }^{* * *} \mathrm{CV}=$ Coefficient of variation.

\section{(2) SAVI Temporal Profile}

Figure 6 shows the SAVI time profile of crambe in the 2014 and 2015 harvests. The indices showed a behaviour similar to that of the NDVI time profile. Our results are in agreement with the findings obtained in a study comparing SAVI, NDVI and LAI values of vegetation coverage in Mato Grosso do Sul, Brasil (Braz, Águas, \& Garcia, 2015). 


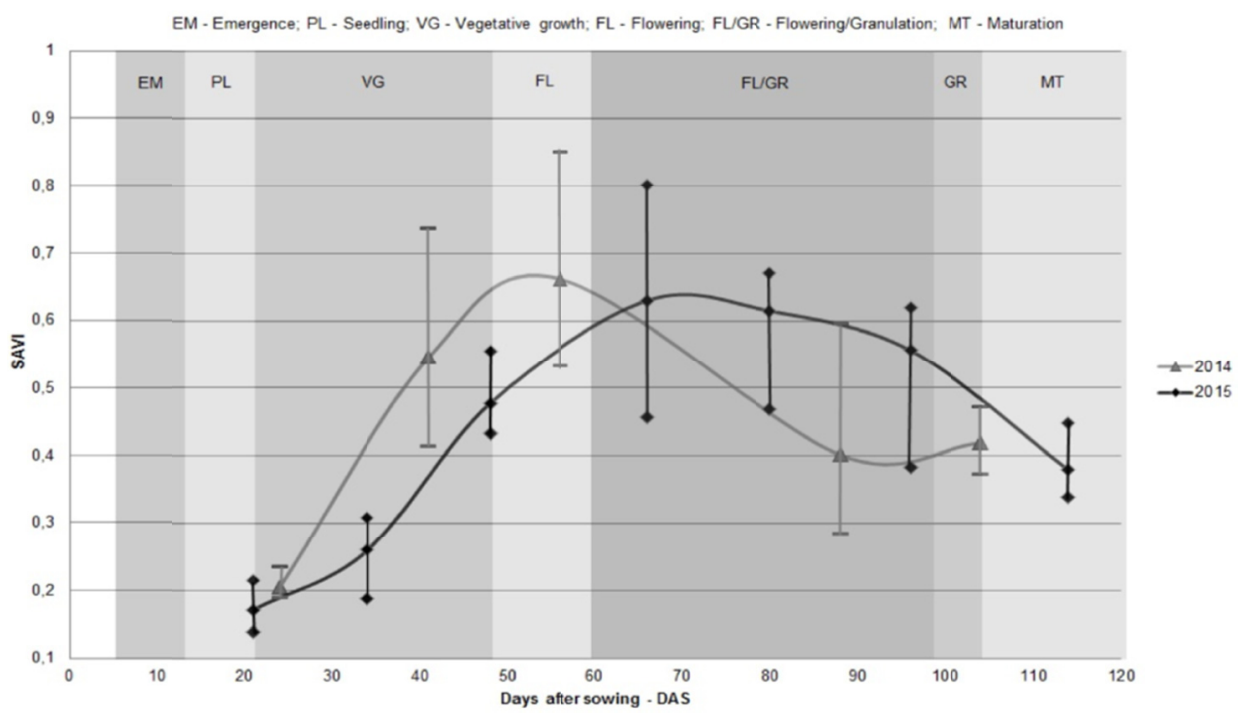

Figure 6. Maximum and minimum values and curve composed by daily means of the Soil-Adjusted Vegetation Index - SAVI of crambe, 2014 and 2015 harvest

The lowest SAVI indices of crambe were identified at the beginning of the crop cycle, phenological stages of PL and early VG, 0.21 in 24 DAS in the 2014 harvest and 0.21 in 21 DAS of the following year. There was an increase in SAVI values until the vegetative growth peak, reaching 0.66 (56 DAS - 2014) and 0.63 (66 DAS 2015). After this development stage, the index values reduced until reaching MT with values of 0.42 in 2014 and 0.38 in 2015.

In the transverse lines of Figure 6, which represent the minimum and maximum values of SAVI, there was an increase of dispersion between these values when compared to those obtained by NDVI, mainly in the FL and GR stages, at 56 DAS in 2014 and 66 and 80 DAS in the 2015 harvest. This fact is related to NDVI saturation under a canopy with a high LAI value and green biomass (Zanzarini et al., 2013).

According to Ponzoni et al. (2012), under soil conditions with mean vegetation coverage, soil brightness increases the vegetation index values. With the insertion of the constant "L", SAVI minimised the soil effect in the VI values. Therefore, the results were lower than the NDVI, demonstrating greater proximity to the real spectral-temporal characteristics of crambe. These results are similar to those obtained by Santos, Nicolete, Filgueiras, Leda and Zimback (2015) in the mapping of irrigated area surfaces by Landsat-8 images and by Almeida et al. (2015) in the LAI estimation of eucalyptus by vegetation indices.

The time profiles of crambe with NDVI and SAVI show that the crop tends to present linear growth of the vegetation indices until the vegetative peak, characterised between the end of the phenological stage of the VG and early FL, when the plant shows higher amounts of green biomass. After this period, the formation and filling of grains, yellowing of leaves and senescence begin, reducing the NDVI, SAVI and crambe biomass values.

\section{Conclusions}

With the use of the terrestrial sensor FieldSpec $\AA 4$ Hi-Res and the applied methodology, we spectral-temporally characterised the crambe crop, generating subsidy to delimit the cultivated areas with the crop via orbital sensors.

The spectral-temporal pattern of the crambe showed absorption peaks in the blue and red ranges and higher reflectances in the NIR in the phenological stages of vegetative growth - VG and beginning of flowering - FL of the crop (between 56 and 66 DAS).

The spectral-temporal patterns from the NDVI and SAVI vegetation indices were similar, with linear growth until the vegetative growth - VG and beginning of flowering - FL stages (between 56 and 66 DAS) and declining indices until reaching maturation.

\section{Acknowledgements}

We are grateful to the R\&D Program Copel Distribuição S.A. for the inputs for implanting the experimental area (project PD-2866-0258/2011 - Assessment of crambe oil as insulating fluid in transformers and agroindustrial 
development of the crop). We also thank the CNPq (National Council of Scientific and Technological Development) and CAPES (Coordination of Improvement of Higher Education Personnel) for financial assistance and the Laboratory of Geoprocessing and Topography - GEOLAB of the UNIOESTE for help with data collection in the field.

\section{References}

Almeida, A. Q., Ribeiro, A., Delgado, R. C., Rody, Y. P., Oliveira, A. S., \& Leite, F. P. (2015). Índice de Área Foliar de Eucalyptus Estimado por Índices de Vegetação Utilizando Imagens TM - Landsat 5. Floresta e Ambiente, 22(3), 368-376. https://doi.org/10.1590/2179-8087.103414

ASD Inc. (Analytical Spectral Devices). (2012). FieldSpec ${ }^{\circledR} 4$ User Manual. ASD Document 600979. Boulder, CO: ASD Inc.

Bendini, H. N., Jacon, A.D., Pessôa, A. C. M., Pavanelli, J. A. P., Moraes, W. S., Ponzoni, F. J., \& Fonseca, L. M. G. (2015). Caracterização Espectral de Folhas de Bananeira (Musa spp.) para detecção e diferenciação da Sigatoka Negra e Sigatoka Amarela. XVII Simpósio Brasileiro de Sensoriamento Remoto. João Pessoa, Brasil: INPE. Retrieved from http://www.dsr.inpe.br/sbsr2015/files/p0511.pdf

Braz, A. M., Águas, T. A., \& Garcia, P. H. M. (2015). Análise de índices de vegetação NDVI e SAVI e índice de área folear (IAF) para a comparação da cobertura vegetal na bacia hidrográfica do córrego ribeirãozinho, município de Selvíria - MS. Revista Percurso, 7(2), 05-22. https://doi.org/10.4025/revpercurso.v7i2.28758

Bredemeier, C., Variani, C., Almeida, D., \& Rosa, A. T. (2013). Estimativa do potencial produtivo em trigo utilizando sensor óptico ativo para adubação nitrogenada em taxa variável. Ciência Rural, 43(7), 1147-1154. https://doi.org/10.1590/S0103-84782013005000080

Coutinho, A. C., Esquerdo, J. C. D. M., Oliveira, L. S., \& Lanza, D. A. (2012). Avaliação de metodologia para o mapeamento e monitoramento da agricultura brasileira. $4^{\circ}$ Simpósio de Geotecnologias no Pantanal (pp. 364-372). Bonito, Brasil: Embrapa Informática Agropecuária/INPE. Retrieved from https://ainfo.cnptia. embrapa.br/digital/bitstream/item/70799/1/p75.pdf

Datt, B. (1998). Remote sensing of chlorophyll a, chlorophyll b, chlorophyll $a+b$, and total carotenoid content in Eucalyptus leaves. Remote Sensing of Environment, 1(66), 111-121. http://doi.org/10.1016/S0034-4257 (98)00046-7

EMBRAPA (Empresa Brasileira de Pesquisa Agropecuária). (2011). Mapa de solos do Brasil. EMBRAPA: Retrieved from http://1drv.ms/1Nv2UpS

Genú, A. M., \& Demattê, J. A. M. (2012). Espectrorradiometria de solos e comparação com sensores orbitais. Bragantia, 71(1), 82-89. https://doi.org/10.1590/S0006-87052012005000005

Huete, A. R. (1988). A Soli-Adjusted Vegetation Index (SAVI). Remote Sensing of Environmental, 25(3), 295-309. https://doi.org/10.1016/0034-4257(88)90106-X

Huete, A. R., Justice, C. O., \& Liu, H. Q. (1994). Development of vegetation and soil índices for MODIS-EOS. Remote Sensing of Environmental, 49(3), 224-234. https://doi.org/10.1016/0034-4257(94)90018-3

IAPAR (Instituto Agronômico do Paraná). (2011). Cartas climáticas do Paraná - Classificação climática. Londrina, PR: IAPAR. Retrieved from http://www.iapar.br/modules/conteudo/conteudo.php?conteudo=863

Inoue, Y., Penuelas, J., Miyata, A., \& Mano, M. (2008). Normalized difference spectral indices for estimating photosynthetic efficiency and capacity at a canopy scale derived from hyperspectral and $\mathrm{CO}_{2}$ flux measurements in rice. Remote Sensing of Environmental, 122, 156-172. http://doi.org/10.1016/j.rse.2007. 04.011

Jasper, S. P., Biaggioni, M. A. M., Silva, P. R. A., Seki, A. S., \& Bueno, O. C. (2010). Análise energética da cultura do crambe (Crambe abyssinica Hochst) produzida em plantio direto. Engenharia Agrícola, 30(3), 395-403. https://doi.org/10.1590/S0100-69162010000300004

Jensen, J. R. (2009). Sensoriamento Remoto do Ambiente: Uma perspectiva em Recursos Terrestres (2nd ed.). J. C. N. Epiphanio. São José dos Campos, SP: Parêntese Editora.

Knights, E. G. (2002). Crambe: A North Dakota case study. Australia: The Regional. Retrieved from http://www.regional.org.au/au/asa/2003/c/11/knights.htm 
Kross, A., Mcnairn, H., Lapen, D., Sunohara, M., \& Champagne, C. (2015). Assessment of RapidEye vegetation indices for estimation of leaf area index and biomass in corn and soybean crops. International Journal of Applied Earth Observation and Geoinformation, 34, 235-248. http://doi.org/10. 1016/j.jag.2014.08.002

Leivas, J. F., Andrade, R. G., Teixeira, A. H. C., Victoria, D. C., Torresan, F. E., \& Bolfe, E. L. (2013). Dinâmica espaço temporal do NDVI em mesorregiões produtoras de milho segunda safra. Campinas, Brasil: Embrapa Monitoramento por Satélites. Retrieved from https://www.embrapa.br/busca-de-publicacoes/-/publicacao/ 985364/dinamica-espacotemporal-do-ndvi-em-mesorregioes-produtoras-de-milho-segunda-safra

Li, Y., Zhou, Q., Zhou, J., Zhang, G., Chen, C., \& Wang, J. (2014). Assimilating remote sensing information into a coupled hydrology-crop growth model to estimate regional maize yield in arid regions. Ecological Modelling, 291, 15-27. http://doi.org/10.1016/j.ecolmodel.2014.07.013

Lohmann, M., Deppe, F., Simões, K., \& Mercuri, E. G. F. (2009). Monitoramento da evolução temporal da cultura da soja no estado do Paraná utilizando imagens TERRA/MODIS. XIV Simpósio Brasileiro de Sensoriamento Remoto (pp. 263-269). Natal, Brasil: INPE. Retrieved from http://marte.sid.inpe.br/ col/dpi.inpe.br/sbsr@80/2008/11.17.18.32.52/doc/263-269.pdf

Martins, D. M., \& Galo, M. de L. B. T. (2015). Caracterização espectral da cana-de-açúcar infectada por nematoides e Migdolus fryanu por espectrorradiometria de campo. Boletim de Ciências Geodésicas, 21(4), 783-796. https://doi.org/10.1590/S1982-21702015000400046

Monteiro, P. F. C., Angulo Filho, R., Xavier, A. C., \& Monteiro, R. O. C. (2013). Índices de vegetação simulados de diferentes sensores na estimativa das variáveis biofísicas do feijoeiro. Pesquisa Agropecuária Brasileira, 48(4), 433-441. https://doi.org/10.1590/S0100-204X2013000400012

Moraes, E. C de. (2009). Fundamentos de Sensoriamento Remoto. Cursos de curta duração. São José dos Campos, SP: Divisão de Processamento de Imagens, DGI/INPE.

Motomiya, A. V. A., Valente, I. M. Q., Molin, J. P., Motomiya, W. R., Biscaro, G. A., \& Jordan, R. A. (2014). Índice de vegetação no algodoeiro sob diferentes doses de nitrogênio e regulador de crescimento. Semina: Ciências Agrárias, 35(1), 169-178. https://doi.org/10.5433/1679-0359.2014v35n1p169

Mulla, D. J. (2013). Twenty five years of remote sensing in precision agriculture: Key advances and remaining knowledge gaps. Biosystems Engineering, 114, 358-371. http://doi.org/10.1016/j.biosystemseng.2012. 08.009

Nguy-Robertson, A., Gitelson, A., Peng, Y., Viña, A., Arkebauer, T., \& Rundquist, D. (2012). Green leaf area index estimation in maize and soybean: Combining vegetation indices to achieve maximal sensitivity. Agronomy Journal, 104, 1336-1347. https://doi.org/10.2134/agronj2012.0065

Oliveira, M. B. de, David, A. M. S. de S., Amaro, H. T. R., Assis, M. de O., Rodrigues, B. R. A., Aspiazú, I., \& Carvalho, A. B. de. (2014). Épocas de colheita e qualidade fisiológica de sementes de crambe. Semina: Ciências Agrárias, 35(4), 1785-1792. https://doi.org/10.5433/1679-0359.2014v35n4p1785

Oliveira, R. C. de, Aguiar, C. G. de, Viecelli, C. A., Primieri, C., Barth, E. F., Bleil Junior, H. G., ... Parizotto, R. R. (2013). Boletim técnico - Cultura do crambe (1st ed.). Cascavel, PR: Faculdade Assis Gurgacz.

Pimentel-Gomes, F., \& Garcia, C. H. (2002). Estatística aplicada a experimentos agronômicos e florestais Exposição com exemplos e orientações para uso de aplicativos (Vol. 1). Piracicaba, SP: FEALQ.

Pitol, C., Broch, D. L., \& Roscoe, R. (2010). Tecnologia e produção: Crambe 2010. Maracaju, MS: Fundação MS.

Poelking, E. L., Lauermann, A., \& Dalmolin, R. (2007). Imagens CBERS na geração de NDVI no estudo da dinâmica da vegetação em período de estresse hídrico. Simpósio Brasileiro de Sensoriamento Remoto (Vol. 13, pp. 4145-4150). Florianópolis, Brasil: INPE. Retrieved from http://marte.sid.inpe.br/col/dpi.inpe.br/ sbsr@80/2006/11.15.19.18.33/doc/4145-4150.pdf

Ponzoni, F. J., Shimabukuro, Y. E., \& Kuplich, T. M. (2012). Sensoriamento remoto da vegetação - Atualizada e ampliada (2nd ed.). São Paulo, SP: Oficina de textos.

Risso, J., Rizzi, R., Rudorff, B. F. T., Adami, M., Shimabukuro, Y. E., Formaggio, A. R., \& Epiphanio, R. D. V. (2012). Índices de vegetação Modis aplicados na discriminação de áreas de soja. Pesquisa Agropecuária Brasileira, 47(9), 1317-1326. https://doi.org/10.1590/S0100-204X2012000900017 
Rouse, J. W., Hass, R. H., Schell, J. A., \& Deering, D. W. (1973). Monitoring vegetation systems in the Great Plains with ERTS. Earth Resources Technology Satellite Symposium (Vol. 3, pp. 309-317). Washington, EUA: NASA.

Santos, J. E. O., Nicolete, D. A. P., Filgueiras, R., Leda, V. C., \& Zimback, C. R. L. (2015). Imagens do Landsat8 no mapeamento de superfícies em área irrigada. Brazilian Journal of Irrigation and Drainage, Edição Especial, 30-36. https://doi.org/10.15809/irriga.2015v1n2p30

Santos, J. I., Silva, T. R. B., Rogerio, F., Santos, R. F., \& Secco, D. (2013). Yeld response in crambe potassium fertilizer. Industrial Crops and Products, 43, 297-300. http://doi.org/10.1016/j.indcrop.2012.07.043

Silva, T. R. B., Reis, A. C. S., Nolla, A., Arieira, C. R. D., Silva, C. A. T., Gouveia, B. T., ... Arieira, J. O. (2013). Nitrogen top dressing application and growing season of crambe cultivated on two crop year. Journal of Food, Agriculture \& Environment, 7(3\&4), 1463-1466. Retrieved from http://world-food.net/download/ journals/2013-issue_3\&4/2013-issue_3\&4-environment/e1.pdf

Soudani, K., Delpierre, N., Pontailler, J. Y., Aubinet, M., Bonal, D., Caquet, B., ... Dufrêne, E. (2013). Ground-based Network of NDVI measurements for tracking temporal dynamics of canopy structure and vegetation phenology in different biomes. Remote Sensing of Environment, 123, 234-245. http://doi.org/10.1016/j.rse.2012.03.012

Sousa Junior, J. G. A., Demattê, J. A. M., \& Genú, A. M. (2008). Comportamento espectral dos solos na paisagem a partir de dados coletados por sensores terrestre e orbital. Revista Brasileira de Ciência do Solo, 32, 727-738. https://doi.org/10.1590/S0100-06832008000200027

Souza, R. S., Chaves, L. H. G., Fernandes, J. D., \& Vasconcelos, A. C. F. (2016). Growth and production of crambe submitted to doses of nitrogen and potassium. American Journal of Plant Sciences, 7, 8-16. https://doi.org/10.4236/ajps.2016.71002

Viana, O. H. (2013). Cultivo de crambe na região oeste do Paraná (Master's thesis, Universidade Estadual do Oeste do Paraná - UNIOESTE, Cascavel, Paraná, Brazil). Retrieved from http://projetos.unioeste.br/pos/ media/File/energia_agricultura/pdf/Dissertacao_Octavio_Viana.pdf

Viana, O. H., Santos, R. F., Oliveira, R. C., Secco, D., Souza, S. N. M., Tokura, L. K., ... Gurgacz, F. (2015). Crambe (Crambe abyssinica $\mathrm{H}$.) development and productivity under different sowing densities. Australian Journal of Crop Science, 9(8), 690-695. Retrieved from http://www.cropj.com/viana_9_8_2015_690_ 695.pdf

Viña, A., Gitelson, A. A., Nguy-Robertson, A. L., \& Peng, Y. (2011). Comparison of diferente vegetation índices for the remote assesment of green leaf área index of crops. Remote Sensing of Environment, 115(12), 3468-3478. http://doi.org/10.1016/j.rse.2011.08.010

Yao, F., Tang, Y., Wang, P., \& Zhang, J. (2015). Estimation of maize yield by using a process-based model and remote sensing data in the Northeast China Plain. Physics and Chemistry of the Earth, 87, 142-152. http://doi.org/10.1016/j.pce.2015.08.010

Zanzarini, F. V., Pissara, T. C., Brandão, F. J. C., \& Teixeira, D. D. B. (2013). Correlação espacial do índice de vegetação (NDVI) de imagem Landsat/ETM+ com atributos do solo. Revista Brasileira de Engenharia Agrícola e Ambiental, 17(6), 608-614. https://doi.org/10.1590/S1415-43662013000600006

\section{Copyrights}

Copyright for this article is retained by the author(s), with first publication rights granted to the journal.

This is an open-access article distributed under the terms and conditions of the Creative Commons Attribution license (http://creativecommons.org/licenses/by/4.0/). 